\title{
A proposed model-based training program to develop the teaching performance of science teachers in Islamic high schools
}

\author{
Dr. Muhammed Abdulqahar Dawood ${ }^{1}$, Dr. Jennad Abdelouahab ${ }^{2}$ \\ ${ }^{1}$ Director of curricula and development department - Department of religious education and Islamic studies \\ ${ }^{2}$ Psychology and Educational Sciences
}

\begin{abstract}
The aim of the current research is to know the effect of a proposed program for professional development based on modules for science teachers in Islamic high schools in Iraq, and to achieve the research objectives, a list of the teaching performances necessary to develop the teaching performance of science teachers was built, and through those training needs a proposed program for the development of these teaching performances was built based on (Modules), and an achievement test was built to measure the cognitive side and a note card to measure the skill side.

The achievement test and the observation card were applied beforehand to the research group, then the proposed program was presented to them, then the achievement test and the observation card were presented to them afterward, and by measuring the differences between the results of the pre and post application of the achievement test and the observation card, it was found that the proposed program is effective in developing the knowledge and skills side of science teachers The research sample, and in light of the research results, the researcher presented a set of recommendations and suggestions.
\end{abstract}

Key words: Professional development - modules - teaching performance.

\section{Introduction}

Education is considering the product and the consumer at the same time to high levels of manpower. If the education serves all other consumers of the workforce, so the teachers are thinking makers. We entrust to them by millions of minds that needs fact, need for Guidance, seeking for knowledge. Nascent minds are in Formation stage. These minds will give a lot in case of preparing rational education and apropos teaching. Teacher is the spirit and core of the educational process. He represents the first brick in the education building, in spite of the importance of good Curriculum, attractive book and the typical building. But all these things will be important after the distinguished, strong and faithful teacher in performance of his work, most versed in his profession. There is no curriculum, how well planned, can exceed the level of teachers (Warorthan, 2007: 13).

As a result, educational development and school reform have taken the priority in the field of the educators thought. Their concern was to develop the educational reality in all its aspects. However, the greatest interest was placed on science teachers due to the fact that they are the main pillars in the development and scientific modernization process. As they are also the main guiders to the scientific educational process. Also they are responsible for accomplishing a large part of the educational system goals (Kanaan, 2007: 3).

The science curricula are one of the most sought after by the developed countries. They desire to reach to the secrets and capabilities of science because this science contains the secrets of energy, atom, laser, etc. Also they try to approach this science to be well -perceived and understood by learners. for students. The science curricula are also considered one of the most difficult scientific courses from intermediate up to postgraduate level, with students trying to avoid these courses because of their difficulties, so their number are less compared with those studying other courses (Erdemir, 2009: 2).

The understanding ability of the science teacher to his material comes from his real desire to improve and raise his scientific efficiency of that material according to his actual needs. This will help him to adjust his students' behavior and give them optimistic attitudes toward science, because the teacher's behavior will imitate on his student behavior. Any improvement on teacher's level will appear on his students' achievement (Taher, 2010: 32).

Several international projects have appeared which interested in teacher and teaching science, that contain: (Najdi and others., 2002: 31), (Nashwan, 2001: 73-70) 


\section{1-Project of the Physical Science Study Committee} (PSSC)

.Harvard Science Project in the United States of America.2-

\section{. - The British Nafield Project 3}

.4 -Arab Pioneer Project for Science Teaching

Development in Arab Countries

These projects have stressed on the development of science education and learning through:

1-Revealing unity and coherence between different science subjects, and exhibit the continuous change in them.

2-Emphasizing that science is a study growing field, and this growth is only human effort imagination.

3 -Focusing on students' understanding to the main perceptions, laws and ideas in science.

4 -The selection of science program subjects in modern physics that should be gradual from simple to familiar to abstract ideas.

5- Increasing students' ability to read systematically and distinguishing what is necessary from what is superficial.

6-Providing students with a strong scientific basis, especially those who will carry. on their studies in science at the university level.

7-Developing students' skill by using laboratory tools and simple materials.

Employing the facts that students had learned in new life situations. 8-

9-Developing students' skill in observation and classification.

In order to accomplish mainly these aims of teaching and learning science, the effective science teacher, who has the ability to achieve these trends and aims, should be emphasize on, through:

1- Good perception of specialized scientific knowledge (Mastering the knowledge content that he studies)

2- Having knowledge in pedagogical knowledge, representing in teaching and learning theories, student understanding, knowledge of theories and principles of classroom behavior and the classroom management.

3-The ability to use techniques through studying content, and understanding the way to present the scientific topics and explain these topics in the classroom.

4-Have positive trends towards the topics which they are studying (Maija, A., Jane, J,2006:207)

Structural theory is considered one of the cognitive psychology theories, which focuses on the mental processes inside the science teacher brain and how to acquire knowledge and organizing and storing methods in memory. It also deals with the way of use this knowledge in the achievement of more learning and thinking.

Research and previous studies conducted in Iraq indicated the weakness of training programs used to develop the science teachers professionally, as in Al-Alwen's (2004), Had's (2011), and Makawun's (2011) and the lack of training programs for science teachers in Islamic high schools in Iraq. All of these reasons had led to weaken their teaching performance.

2-The notes and opinions of profession Supervisors in the Islamic high schools had indicated the low level of teaching performance to the science teachers. They attributed this to the lack of training programs which treat this weakness, and provide an opportunity to guide them, as well as exchanging of Points of view and experiences among teachers themselves.

it was a strong index for researchers to the serious need to develop the teaching performance to science teachers by preparing and building training programs.

Problem: The problem of research is reflected in the "weak and low level of training programs presented to Islamic high school teachers and these programs do not meet their teachers' needs.

In order to address this problem, the researchers try to answer the following main question:

What is the usefulness of a proposed model-based training program to improve the teaching performance of science teachers in Islamic high schools?

The following sub- questions have emerged from the main one:

1-What are the basics of proposed model-based training program to develop the teaching performance of science teachers in Islamic high schools?

2- What is image of the proposed model-based training program to improve the teaching performance of Islamic high sciences teachers?

3- What is the effectiveness of proposed modelbased training program to develop the teaching performance of science teachers in Islamic high schools?

Goals

1-Determining training needs to develop the teaching performance of the Islamic high school 
teachers and define the weaknesses in their teaching performance.

2-Preparing the proposed model-based training program to develop the teaching performance of the Islamic high sciences teachers and identify the effectiveness of the proposed program to develop the teaching performance for the teachers of science in Islamic high schools.

\section{Significance:}

This research is hoped to be significant for the following:

1- To response to the national needs for the development of educational institutions through training programs for science teachers in Islamic high schools.

2-To build a training model-based program to develop the teaching performance of science teachers in Islamic high schools.

3- To determine the training needs that must be met in the teachers of science in Islamic high schools.

4-To show the importance of using models as a guide and instructor for training programs, as many studies had confirmed this idea.

\section{Population and Sample}

The research population consists of science teachers in Islamic high schools. The research sample covers the teachers of science in Islamic high schools. They are 22 science teachers from the Islamic high school and Islamic studies.

\section{Objective Limits}

\section{.Objective limits: 1}

The current research is limited to the application of a proposed model-based on training program for the development of teaching performance and that includes:

.A-Methods of teaching and learning science

B- Techniques and technology of science education and learning.

2-Time Limits: Implementing the proposed program to improve the teaching performance of Islamic secondary school teachers for the academic year (2017-2018)

3-Spatial Limits: a group of science teachers in the Islamic secondary schools of Baghdad governorate.

\section{Tools}

1-List of training needs of science teachers in Islamic high schools

2-The cognitive approach of the program for science teachers in Islamic high schools.

3- Teaching performance note card to science teachers in Islamic high schools.

\section{Research Basic terms}

Models:

Jamel (2000: 45). defines model as "a small learning unit based on self-learning principle and the parting of education. This unit includes specific objectives and learning experiences that are organized in logical sequence to help the learner to achieve the goals and develop abilities according to predefined levels of proficiency and his personal speed.

Mahmoud and Abdel Hamid (2006: 12) give a definition of a model as "a small educational unit inside a set of Sequential and integrated units including in an educational program. Its content designed to achieve specific learning objectives. These objects are taught individually over a period of time. The learner studies them according to his speed and ability. It includes a set of near-term objectives formulated in procedural form. It includes educational activities and exercises that simplify the learning process on learner. It could be measured by a note -referenced card.

Victorina, Eveleyn \& Herminia defined model as a "self-contained educational unit focusing mainly on the objectives which should be achieved through a set of educational activities that help the learner to master in accordance with his abilities (Victorina, Eveleyn \& Herminia, 2004)

From the point of view of Mahmoud (2003), the module is defined as "a small independent educational unit within an organized and sequenced group of small educational units formulated as a set of standards for real teaching in the form of an organized educational program. It is carefully planned to achieve specific goals, allowing the learner to practice various activities to acquire knowledge, skills and some higher thinking patterns according to his abilities and willingness to pass a certain level of learning in a limitless time depends on the length and quality of the unit's objectives and content.

Arafa (2006) sees the module as a "minieducational unit that includes educational activities. It designed to be independent and selfcontained, in addition to a list of precise targets, diagnostic formative and summative tests, the influential and concluding and appropriate for them.

Al-Wasim (2003) defines it as a "mini-educational unit that includes educational activities to allow the learner to self-learn according to his tendencies, Readiness and abilities to achieve limited learning objectives." 
The two researchers define the educational module as procedural: "a mini- educational unit within a proposed program containing a number of units. It has a predefined procedural objectives and educational learning activities. The teachers of science at the Islamic high schools (the research group) depend on their study of the model, according to their speed, tendencies and selfabilities. they choose from the activities what fits and helps them to develop their teaching performance to reach the specific level of proficiency.

\section{Operational Definition of the Model-based} Training Program

"A model-based program includes a set of goals, educational experiences, activities, teaching assistances, planning, assessment, feedback, input, processes, and outputs, which demonstrate all the relationships between them. It enables the science teacher to achieve the educational goals set".

Concept of the Performance

"It is what comes from the individual's spoken or moral behavior. it is based on a particular cognitive and emotional background. This performance is usually at a certain level showing the ability to perform an action " (Laqani and Ali, 2003: 2).

\section{Teaching performance}

1. (Diab and Adel, 2001: 35): " Teacher's behavior or effort to achieve the desired objectives according to a set rules of rules and codes governing that organize his/her work like planning and preparation, teaching implementation, estimation of learners' performance and the related professional responsibilities.

2- (Al-Janabi, 2002: 756): "The process of measuring and determining the extent of teacher performance in the educational situation in the classroom and within a specified period of time."

\section{Definition of the teaching performance procedural}

It is the performance of science teacher at Islamic high schools. It includes of educational practices and teaching implementation in the classroom according to the program based on the models to positively reflect on his teaching performance. It can be witnessed and measured by the standards prepared for this purpose.

\section{Theoreticall framework and Previous Related} studies

\section{Educationall Models}

The model is a specified mini-educational unit within an integrated and harmonized set of educational units. It formats specific educational program known by an educational package. This unit is based on self-learning principle and learning individualization. The unit includes specific goals and experiences and learning activities. It is organized in a logical regularity. This is going to help the learner to achieve the goals and develop his skills according to his proficiency level, capacity and Self-speed that have been defined previously. This is done under the supervision and guidance of the teacher. Length, quality, goals and content of unit with learner speed will limit the required time to master the unit. (Tamam and Omaima, 2010).

(Warwich 1996) sees that model is a unit of study materials. It has been studied as self -learning. The study of unit may include specific subject or a point within this subject in a Consecutive way that concern with the Individual needs for every learner. Characteristics: Educational Model

Educational models have a set of basis, principles and characteristics. They make educational modules a distinctive way for learning, training and professional development for teachers (Jammel, 2000: 42).

- following specific systematic approach with models:

When designing the educational model, it is necessary to identify educational goals. These goals must be formulated in a form of behavioral goals, choosing the educational materials and drawing a plan study for the model in studying. Also, such goals should identify situations, scientific activities and put tests in order to achieve the desired goals. The use of the educational materials, tools and self-sufficient teaching aids. These materials serve the trainees' learning objectives to one subject of the learning ones. The models provide a variety of experiences that encourage the trainee to participate actively in learning. The models represent a coordinated and organized program in an integrated form.

-Consideration of the individuals' differences between students and trainees:

Consideration of the individual's differences between students and trainees is one of the main goals for the educational models. It provides the best opportunities through accurate diagnosis for every learner. It offers an alternative variety of methods, activities and means to enable the learner to choose the appropriate for him/her. Therefore, the models are suitable for all learners' classes and facing the problem of individual differences through: 
-Identifying the start-up activity.

The model allows each trainee to begin studying the program according to the previous level of knowledge that will result from the future tests.

-Listing of activities, teaching aids and sources of knowledge

and each trainee chooses what appropriate for him.

\section{- Correlation and Sequence in Building and Organizing Knowledge:}

When designing and preparing an educational program consisting of educational models, these models are designed and prepared independently, and they are in correlation and sequence to help accomplishing the model study which help to reach to the next model. Thus, the educational program as a whole is completed in a sequential and organized image. There is a correlation between the model components, so the appropriate sequence of the educational material can be accomplished.

-Paying Interest to the learner as the core of educational process:

The models make the learner the core of the educational process and transfer interest from teacher to the learner. They are concerned with the mastery of learning in predetermine ratio. Models also provides the learner with what supports the educational process like tools and various activities. They put in account learner's intellectual, temporal and spatial potentials. They make the teacher a co-factor and director in the learning process. He participates in the educational process planning and describes the appropriate activities. $\mathrm{He}$ also helps to overcome obstacles that face learner education (trainee).

- Direct reinforcement for answer:

Skinner's studies and results on the subject of reinforcement are an important basis for program education and learning through educational models. The teacher who trains through models can achieve direct reinforcement after answering the question through the answer sample provided by the model. So, the repetition of reinforcement has achieved greater than what might happen in the training room with large numbers of trainees.

- Available of Specific Strategies for Evaluation: The trainee is not allowed to move from one model to another until mastering the previous model objectives. Thus, for the other models, such a method reduces the trainee teacher failure to learn. Also, it contributes to ensure that trainee has achieved the required understanding and learning for the subject of the first model before moving to the next model. The evaluation in module should be conducted in advance to find out the learner's education readiness, and systematically the level of progress in the learning process, and periodically to find out the extent of model goals achievement.

\section{- Availability of an Acceptable Level of} Proficiency (Mastery):

Usually, models of educational units require an acceptable level of

Proficiency. It should not less than $(80 \%)$. It is not allowed to move from one model to another unless mastering the previous one with predefined proficiency level. In case of the proficiency desired level is not reached, the opportunity to re-learn is possible and thus ensures the achievement of the desired goals.

\section{- Models Make the Learning Process Meaningfull and Active: \\ and Effat, 2006: 54).}

In self-learning that based on the models, the learning process is meaningful and active, in that learners depend on themselves in the educational situations. This will generate a greater challenge to overcome such situations, as well as the educational models provide the leaner greater opportunity to gain the skill of using devices and tools through the interaction of the teacher trainee when studying the models. Moreover, models offer the learner more opportunity to exercise the skills and abilities of the scientific thinking, such as research, observation, draw conclusion and others.

- Objectives are determined and formulated as Scientific Results:

Objectives are determined and formulated in models in forms of educational results that clarify to the learner the types of education and levels that should be achieved and their levels and educational materials that contained in the models as well as methods, alternatives and means of evaluation that are not intended in themselves. All the above are to be used to facilitate the process of education and learning. In addition to the characteristics and features of former models, they also have several features when compared to the traditional methods of professional development. This can be shown in the following table (Sherbini and Effat, 2006: 54). 
As a result, for the previous models characteristics as a method for self-learning so the two researchers have chosen this type of learning. These characteristics have a significance to improve teachers' performance and avoid shortcomings of traditional training methods followed by the Ministry of Education in Iraq for training in service teachers. This method also takes into account the teachers' temporal and spatial looking for information.Several studies have confirmed the activity of using educational models as compared with traditional methods in training of in-service teachers such as : (Abu Al-Hamwil, 2005), (Hebrew, 2009), (Anubusidi, 2005) and the effectiveness of educational modules in improving the applicants performance such as :(Shahab and Umniah, 1998), (Jamel, 1995).

2. Educational Model Components: Throughout

\begin{tabular}{|c|c|c|c|}
\hline Subject & Type of Comparison & Learning by Models & Learning by Traditional Methods \\
\hline $\mathrm{A}$ & Goals & $\begin{array}{l}\text { Goals are determined in a behavioral image and } \\
\text { learner should know it before studying every } \\
\text { model }\end{array}$ & $\begin{array}{l}\text { Objectives are not defined in behavioral form and can } \\
\text { be inferred by the content of the curriculum }\end{array}$ \\
\hline $\mathrm{B}$ & Determination Learners Level & $\begin{array}{l}\text { the level of teachers and their previous } \\
\text { experiences are determined by pre- tests }\end{array}$ & $\begin{array}{l}\text { the level of learners is not determined and they are } \\
\text { provided with content whether they need to study it or } \\
\text { not }\end{array}$ \\
\hline $\mathrm{C}$ & $\begin{array}{l}\text { Organization of Educational } \\
\text { Experiences }\end{array}$ & Presented as educational Models & Presented in the form of courses \\
\hline $\mathrm{D}$ & Learner Role & $\begin{array}{l}\text { The learner is active and positive and acquires } \\
\text { information in accordance with his own speed } \\
\text { and own potentials. }\end{array}$ & $\begin{array}{l}\text { The learner is negative and his role is to receive and } \\
\text { save information }\end{array}$ \\
\hline $\mathrm{E}$ & Role of teacher or trainer & $\begin{array}{l}\text { Guidance, Direction and helping the learner to } \\
\text { choose the skills, methods and activities } \\
\text { appropriate with his abilities and readiness }\end{array}$ & $\begin{array}{l}\text { The role of the teacher is initiation and filling the minds } \\
\text { of learners }\end{array}$ \\
\hline $\mathrm{F}$ & Time allotted for studying & $\begin{array}{l}\text { There is no specific time Committed by learners. } \\
\text { Every learner takes the time that suits his own } \\
\text { abilities. }\end{array}$ & There is a specific time associated with all learners \\
\hline $\mathrm{G}$ & Place of studying & $\begin{array}{l}\text { The learner does not have a specific place to } \\
\text { study and can learn anywhere in the school or } \\
\text { outside }\end{array}$ & $\begin{array}{l}\text { Education takes place within specific places and it is } \\
\text { subject to a timetable. }\end{array}$ \\
\hline I & Individuals differences & $\begin{array}{l}\text { individual differences are taking into account } \\
\text { between learners and provide a number of } \\
\text { alternatives to learning resources. }\end{array}$ & $\begin{array}{l}\text { It is a single curriculum offered to all learners in all } \\
\text { environments without taking into account the individual } \\
\text { differences between them. }\end{array}$ \\
\hline $\mathrm{L}$ & Learning results & $\begin{array}{l}\text { The performance of the learner is judged by using } \\
\text { the standards of mastering }\end{array}$ & $\begin{array}{l}\text { The performance of the learner is judged by the grades } \\
\text { obtained at the end of course exam. }\end{array}$ \\
\hline
\end{tabular}

conditions through which teachers can study models at times that suit them, in a way that does not affect timetable and disturb conducting lessons in schools, unlike the traditional training programs. Moreover, models to achieve the principle of the teacher's dependence on himself in learning and increasing the learner's eagerness to study programs and activate learners' motivation towards the acquaintance of the two researchers on the previous studies and educational Literature

(Mohammad, 2001), Jammal (2000) and (Najih, 1997) on the components of the model. They concluded to the components of model which will be followed in this research.

- Introduction and Contents (Index).

- Behavioral Objectives. 
- Pre-test.

- Determining Learning Resources.

- Educational Learning Activities and Teaching Aids.

- The Scientific Content of the Model.

- Post-test (same as Pre- test).

- Sample of Responses for Pre and post-tests.

The two researchers concluded that the basic components of the modules in general are:

- Objectives are at different levels (general objective of the module and behavioral goals).

- Content with all its activities that are in accordance with the goals of the model. it is the central and fundamental part of the model.

- Evaluation of various types (pre-and post- test and self-assessment) and in accordance with the goals and content.

The use of educational models in professional development of teachers is a concept that refers to the various knowledge, skills and attitudes that they must be obtained in order to improve their teaching performance. This will be reflected on the improvement of the productions of the educational learning process. It is an important and continuous process to overcome many of the obstacles and disadvantages that are faced teachers' tasks. It is not a random action but is well planned and organized process.

However, in reality the situation refers to the lack of programs for the teaching performance development at Islamic secondary school teachers, especially programs related to secondary school teachers. Even if there are some programs for specific specializations, these programs comprise a lot of Determinants which deviate from achieving their objectives.

\section{Teaching Performance:}

Ibn Sina describes the good teacher when the Arab Islamic state was the fountain of world civilization. He said that the teacher should be reasonable, religious and have an ethical vision. Also, he should be, dignified, and away from puerility. He has to learn how to treat with the pupil and be patient with him (Al-Safafih, 2005: 21).

The modern view to the physic teacher that describes him as a fundamental center in the scientific learning process. The recent trends have concentrated on new and evolving concept to physics teacher role in organizing students learning physic, and a direction that should not depend on initiation, memorizing and direct learning. They have to know how to think and how to reach for knowledge by themselves. They should learn how to reach knowledge and use it in their life. The Teacher is a lecturer, questions respondent and discussion leader. He evaluates and directs activity. As well, the teacher considers an activity facilitator, investigation and exploration companion (Zayton, 2008: 229).

Teaching Performance Concept:

Having a look at some researches and literatures that deals teacher learning performance, the two researchers found many of meanings that given in literatures educational related to this concept. The researchers displayed some of definitions in order to determine the meaning of teaching performance in this research. Before learning about the concept of "teaching performance", performance concept are to be clarified in general as follows:

Performance Concept:

- It is what the individual produces of spoken or skillful behavior. It is based on a specific cognitive and sentimentalism background. Typically, this performance at a certain level shows the ability to do something (Lakani and Ali, 2003: 2).

- "Qualitative educational ability, which is called technical ability. It includes what the teacher says and teaches in the educational situation" (Mohiuddin and Mona, 1999: 174).

There are several different definitions about the teaching performance concept and the most important definitions are the following:

- The teacher ability to carry out practices and procedures that help him to accomplish the teaching process with high efficiency and become the final result of the educational outcomes.

- A set of procedures and behaviors used by the teacher to reinforce his professional aspect such as his teaching practice and to demonstrate his measurable achievement (R.Hawes \& Lynne, 1982: 199).

- A purposeful educational process, in which both of teachers and pupils cooperate to achieve desired educational goals "(Al-Shennawi and Nasr, 1991: 116).

- A set of individual responses in a particular situation that can be observed and measured according to specific principles, thus performance is what is measured of behavior (Saleh, 1999: 11). - the procedural translation of teacher's activities, teaching strategy, course management and contribute in school activities and all other actions that can contribute in student learning progress " (Shehata and Zainab, 2003: 29). 
- It is teacher's behavior or effort to achieve the desire goals according to a set of rules and laws that organize his work (Planning and preparation, teaching implementation, learners performance assessment and what are associated with professional responsibilities). (Diab and Adel, 2001: 35) the researchers adopt operationally this definition in their current research.

Through the previous definitions of teaching performance, it can be concluded that:

1) Teaching performance consists of a series or set of knowledge, skills and attitudes connected to each other to achieve specific goals and outcomes.

2) Teaching performance translates skills, attitudes and knowledge into a series of actions and procedures.

3) Teaching performance is related to the behavioral side because it is a behavioral translation of the skill and ability.

4) Teaching performance is subject to measurement or observation as a teacher acts inside the classroom through his interaction with the pupils while doing his work.

5) The necessity to activate the learner role in the teaching process by considering him the center of the educational process.

Previous Studies:

Cameroon's (2009) study aimed to determine the influence of professional development on teachers' performance development and the relationship between professional development and school administration. The study had concluded that professional development program by using the model lead to develop teachers' performance and workshops which are not enough to develop their performance.

Beege's (2006) study aims to measure the effectiveness of a self-learning program (models) to train science teachers in the primary stage in Egypt to develop their teaching skills in the light of their training needs. The results of study refer to the effectiveness of program in development the Cognitive side and the skillful side for the teachers. Mahmoud and Abdelhamid"s (2006) aimed to find out the impact of the use of educational models on the development of some teaching skills and go toward teaching profession to the students' learners in the college of Education. The results show the effectiveness of the program in development the teaching skills identified in the study and growth of the trend towards the teaching profession for the sample.
Abu Hamai'l, (2005) aimed to measure the effectiveness of a proposed training program for Biology teachers in Saudi Arabia. The study results illustrate that the learning models used have a great influence in providing teachers with cognitive and skillful sides. there is a connection between teacher Cognitive achievement and his skillful performance.

Carolyen"s (2006) study showed the effectiveness of Professional Development Model-based Program in development of Practical application skills and formulating positive attitudes towards science teaching and increasing the science teachers' confidence in themselves through increase of Professional development programs number provided to them.

Mahmood's (2003) aimed to measure the effectiveness of proposed program based on selflearning(modules) used for developing, understanding and practicing of real teaching standards for women science teachers in basic education stage and its relationship with developing the higher thinking skills of their students. The results indicated the effectiveness of this program in acquiring women science teachers the real teaching standards. This was reflected in developing of higher thinking skills of their students.

Askool's (2002) aimed to study the impact of training program to teachers and teachers' women of secondary school. It tries to develop their awareness and production skills by using teaching aids. The results indicated the positive impact of the program on the teaching aids, developing teachers' awareness of the teaching aids and developing their own skills in producing teaching and educational transparencies boards. Also it develops their skills in the production of educational boards and transparencies.

Rudolph's study aimed to find out the impact of training in-service teachers development. The results showed that training programs had an impact in increasing effectiveness, performance development and change of attitude positively.

Kent's (2001) deals with the concept of the professional development and its role played in developing and enhancing the quality of teachers' professional performance, considering professional development an important factor in achieve a balance between theory and practice, hence leading to improve the future of education as a whole. 
Research and Studies dealt with Training Programs:

- Yahya"s (2013) showed the effectiveness of professional development program of biology teacher in the secondary stage. Having used the models method in applying of the program, this study agrees with the current study in using of the models to organize the program scientific material, although the specialization is different.

- Shanita's (2009) confirmed the effectiveness of science teachers training program in Iraq in the light of training needs to develop lesson planning fields and teaching methods, as well as the program impact in improving the achievement level and thinking skills development of science teachers' students (The sample).

- Abd Alrab's (2010) revealed the effectiveness of the professional development program for science teachers in the middle stage in Bahrain in developing the thinking skills of their students. The program was built in the light of science teachers training needs. The program used the models style when applied.

This study is in agreement with the current one in building the training program for science teachers in the light of training needs and using models for organizing the scientific material for program.

- Cameroon's (2009) showed the impact of the professional development on the teachers' performance development, in line with an understanding of link between training programs and school administration. The study concluded that the training programs led to the development of teachers' performance and that the workshops are not enough to develop their performance.

This study agrees with the current one to develop some teaching skills.

-Mahmood and Batrawi's (2006) indicates to find out the impact of educational models use in developing of some teaching skills. It encourages toward teaching profession for students at college of education. The results show the program effectiveness in developing of the teaching skills determined in this study. It also refers to the growth of direction toward teaching profession for college of education students who they are sample of research.

This study with the current one in developing teacher teaching performance and using models for organizing the program scientific material.

-Dillon et. al's (2000), confirmed on instructions and needs of science teachers from training programs in Britain, and identifying the most important training practices in science teaching on training program. Training programs depend on practical activities and conducting the new strategies in teaching.

This study has the same goals set in the current study in developing of teaching performance.

-Anderson's 2000) study aimed to discover the impact of the scientific material teachers' participation in the training programs. The results showed that (90\%) of the study sample had become more effective in their teaching performance, as well as more interested in using of the teaching methods and activities.

This study supports the current one which is using the training programs to develop the teaching and cognitive performance of the science teacher.

Procedures of research

Measurement of science teacher teaching performance

In order to enable the two researchers to follow up and expose the activity of proposed training program and measure the skillful aspect of the proposed program for science teacher performance, they prepared a note card in light of the training requirements which included fields of (methods of teaching science and learning, techniques and science education technology). It will be applied before and after on research group.

Research instruments:

1- Educational material for proposed training program.

2- Note card: to measure the development of teaching performance for science teacher in Islamic secondary school.

3- Preparing and building the proposed program based on the modules in light of the training needs for Islamic secondary school teachers.

\section{Determine bases of preparing proposed training program}

To answer the second sub-question which states on:

(What are the bases of building the proposed training program which based on modules to development the teaching performance for physics teachers in Iraq).

The proposed program has been built and prepared in the light of following bases:

1- Take in consideration the training needs for science teachers which have the impact to achieve the aims of the proposed program to meet their needs, aspirations and ambitions.

2- The proposed training program is based on modules because it has features such as flexibility 
and simplicity of application. It also allows modifications in the items selection or order processing, and the existence of the intensification and feedback during the program design process.

3- Determine the aspects each of teaching performance. Its levels and subjects through training needs which represent in (methods of teaching and learning science, Technologies and science teaching technology).

4- Taking into account the science teacher (trainee) in his positive participation in expressing his opinion in the learning educational activities and the program activates. Also It works to turn him from inactive listener to an active and positive participant during the proposed program.

5- Take in account the features of sciences teachers (trainees) which the proposed program will present for them according to their different capabilities and potentialities. This could be done through the program's pre-test (diagnostic) to determine the levels and characteristics of each teacher.

6- the logical gradation and sequences which organize the program content and connect it with science procedure which taught by science teacher. it can be translated into educational experiences and performance capabilities that reflect on his behavior and performance.it can be observed during the program while depend on the method of immediate reinforcement and feedback to prove the behavioral objectives achievement.

7- Take into account nature of science material in terms of activities and experiences which should exercise by science teacher during studying proposed program.

8- the program includes activities, experiences and teaching methods to develop the teaching performance.

9- science teacher determines the suitable style to develop his teaching performance and take into account students, needs.

10- develop of science teacher professionally through using modern means such as Such as virtual lab and simulation.

- Building the proposed training program based on modules in Iraq including the following:

- the proposed training program based on modules has built in the light of previous bases which include the following:

determine the title of the proposed training program:

The tile of program has determined (proposed training program based on modules to develop the teaching performance for science teachers in Islamic secondary school).

Determine the main aim for the proposed program which is: develop the teaching performance for science teachers in Islamic secondary school.

the general aims for proposed training program:

- Develop the teaching performance for science teachers in the Islamic secondary school in educational techniques to teach and learn sciences in each of using skills of teaching and learning sciences techniques. It is also deals with the practicing communication skills.

- Develop the teaching performance for science teachers in Islamic secondary schools in the methods of teaching and learning sciences. It used in skill of using science teaching strategies and the skill of encouraging students to solve problems. Also it used in the skill of inquiry and experimentation. As well as used in the skill of managing learning time and reducing its waste. Likewise, the skill of effective utilization for different methods in the motivation of students.

the procedural aims for proposed training program:

Every special aim has divided into procedural aims, it takes in account that the aims should be linked to the general and specific aims for the proposed training program. It must be formulated correctly and clearly, and describe the expected production of science teachers. It should be noticeable and measurable.

It will be displayed when each module of the proposed training program is offered.

- proposed training program The content of

- In order to determine the content of proposed training program a list of training needs for science teachers in Islamic secondary school has adopted. It is also adopted by the two researchers and in many references such as (Abu al-Hamail, 2005), (Al-Nuwaihi, 2010), (Abdel-Qawi, 2010), (Mahmoud and Abdul Hamid, 2006), (Naifah Qatmi, 2004).

The selection and organization of the content of the proposed training program is achieved in accordance with the following steps:

- Prepare a list of topics that can help to achieve the aims of the proposed training program.

Collect the references that address with these topics- 
- Examine the content of those references and select information that meets the aims of the proposed program.

- Usage this information to help in accomplish the aims that set for the proposed program with existence of applications in the field of science.

- Organizing the content of the proposed training program in the form of modules so that each module will deal with one or two fields of teaching performance for science teachers to develop them.

So that the content of the proposed training program has determined according to the following modules:

-The first module: teaching and learning sciences methods.

It contents the following topics:

Discussion Method, Problem Solving, Investigation Methodology, Maps of Concept, Collaborative Learning, Modeling and Simulation, Learning Cycle, Brainstorming.

-The second modulle: educational techniques for teaching and learning sciences.

It contents the following topics: The skill of using educational techniques for teaching and learning sciences, the skill of practicing communication skills.

-Contents and factors of the educational module Every educational module has the following contents:

A-Module title: It is necessary that the title of the educational module is clear and specific to reflect the basic idea of the module, and the science teachers should be versed through reading it, he should have the ability to access to the general idea and summary of the content of each module to stimulate their motivation towards the proposed training program.

B- The introduction: The chart, which is acknowledged by the science teacher in Islamic secondary schools on the components contained in the module, giving a general idea of the content and justifications of his study and raise the motivation of science teachers to study.

C- The behavioral aims: It has determined procedurally to achieve the general aim to all levels of cognitive, skillful and emotional learning.

D- Instructions: It is the steps that show the study progress of the proposed program modules, the nature of the concepts that are included, and it has prepared in steps form and attached with the proposed program modules.

E-Modulle pre-test (Deliberate reference): A test has been formed to determine learning level, skills and information that owned by science teacher which deal with proposed program. If the teacher achieves the required level of proficiency $(85 \%)$ and above, he can move to the next module, but If he does not he will start again studying the model to achieve the level of proficiency specified in the proposed program. This test used in the end of module learning as a Post-test to authenticate the level of mastery of the module scientific subject. A form has set for answer after pre-test and The answer form is on the last page of the module.

\section{F- knowledge Sources}

In addition to the information and skills acquired by the learner (science teacher) from the module and reading the scientific content of the module, it is preferable to have access to some scientific references and Internet sites that related to subjects of educational module.

G- The post-test of module: It is the same of the pre- test that passed by science teacher (trainee) after completion of studying module. It used to determine the achieved extent to the module aims study and the level of achievement and proficiency. It is measured at (85\%) and above. The post-test corrected by science teachers (trainees) according to form of answers which is founded in the end of module. In case of he reaches to the define proficiency level, he will move to study the next module. If he doesn't pass the test, he has to restudy the same module using other alternative.

H-Correction key: It is the form of ideal answers to pre and post- test. Explaining the grades of each paragraph in test questions, where it enables science teachers in Islamic secondary school (trainees) to correct his answer on the test by himself.

\section{I- Scientific references for modulle:}

- Training methods used in proposed program.

Training methods consider of important contains to proposed program which linked with aims and contains of proposed program. So the two researchers had used the method of educational module. every module included different learning methods and activities, such as workshop, discussion, brainstorming, collaborative learning, interactive videos, some active learning methods and problems solving.

-Activities, means and learning instrument that have used in Implementation of proposed program: It is take into account in determine activities and program means that should be varied, realistic and help to provide opportunities for positive participation of science teachers. Also 
there are some of the activities and teaching aids that helped to implement the proposed training program, and achieve its objectives which are:

Educational activities and demonstrations:

A- Reading topics that included in the proposed program through references and websites that deals with the same topics.

B. Watch some educational movies and videos on how to implement science topics using numerous learning and teaching methods such as: surveying, problem solving, discussion, brainstorming, learning, modeling and simulation.

C- writing research paper about one of the aspects that exists in the modules of proposed program and Methodology orientation of scientific research by the two researchers.

D-Share colleagues in writing reports and make applications with each module.

E- Discussion with the two researchers when a problem occurs during the implementation of the activities and demonstrations of the proposed program.

The learning instruments that used in implementation of proposed program:

A. Computers (PC) in the Science Lab.

B. Laboratory devices related to science experiments.

C. Plasma screen to display some educational

\begin{tabular}{|l|l|l|l|} 
C. Plasma screen to display some educational & $\begin{array}{l}\text { The relative weight } \\
\text { of the field }\end{array}$ & $\begin{array}{l}\text { Number of module } \\
\text { hours }\end{array}$ \\
\hline Module number & Module name & $\mathbf{1 4}$ \\
\hline Second module & $\begin{array}{l}\text { Methods of teaching and } \\
\text { learning physics }\end{array}$ & $\begin{array}{l}\text { Technom } \\
\text { teaching and learning physics }\end{array}$ & $\mathbf{3 0 \%}$ \\
\hline Total & & $\mathbf{1 0 0 \%}$ & $\mathbf{2 0}$ \\
\hline
\end{tabular}

movies and videos that related to the proposed training program.

D- (Data Show) Device to display educational movies and videos that related with the scientific content of module.

Methodls and means of assessment used in the proposed training program:

Some evolution methods have been identified in which the objectives of the proposed training program can be judged as follows:

- Pre- evolution:

It helps to determine the Knowledge extent to science teachers (research group) of teaching performance level to be developed and growth where the initial level is determined before the applied of the proposed program. It has been through:
The collecting test to the program scientific content and note card to evolution the teaching performance level for science teachers (research group).

- The formative evolution: It is the evolution that accompanying with the proposed training program. It enables science teachers to correct their course and achieve the determine aims for the proposed program, and that is through:

1- Examine works of science teachers (trainees) for every application of proposed training program applications during their study to the proposed program.

2- Oral questions during their study to the proposed training program which found in the scientific content for every educational module.

- post- evolution: It is done at the end of applied the proposed training program, so the activity of proposed training program in achievement its aims will determine and that is through a note card to evolution the teaching performance for physics teachers in secondary stage (research group) in the light of training needs.

1-. The time plan for implementing the proposed training program:

The time plan to implement the proposed training program has been determined. (Table 2).

Table (2) Shows that the total number of required

hours to implement the proposed training program is 20 hours starting from the first semester of 2018. Table (2) shows that the total number of required hours to implement the proposed training program is 20 hours starting from the first semester of 2018. Table (2)

\section{Adjust the proposed training program}

A- display the proposed training program arbitrators.

After completion of the preparation of the program in its initial form, it has been displayed on the arbitrators in order to know their opinions and notes through their responses on the survey presented to science teachers in Islamic secondary school. Also for the general, specific and 
procedural objectives for the content of the proposed training program, As well as the validity of the content and the scientific organization to the proposed program. Likewise, the relevance each of training methods, proposed educational activities, educational technologies, the methods and means of evolution, the extent to which its objectives are verified, and the proposed timetable for its $\mathbb{B}$ - the survey experience for proposed Professional

development program

The proposed training program was applied on an exploratory sample of science teachers outside the basic sample (research group). There were (10) teachers. They discuss their impressions and opinions on the proposed program. They expressed their satisfaction with the program and expressed on its important and close association with their training needs. Its suitability for applications and activities taking into account individual differences in terms of their potentials and capabilities. It explained the concepts and elements of the proposed program content. In addition to its variety with an interesting style. They referred to some of teaching and learning methods which don't practice to improve their teaching performance. The proposed professional development program took two weeks. In light of the modifications and the above statement, the proposed training program has been adapted to suit the science teachers in Islamic secondary schools. Subsequently it becomes on its final form and valid for applied on research group (Appendix 1). Then the two researchers answered about the second question which was (What is the image of the proposed training program based on module to develop the teaching performance for science teachers in Islamic secondary schools?)

\section{2- The note card}

The nature of current research required preparing a note card to measure the performance of science teachers (research sample) in skillful aspects because it show the real image of how the teacher practices his teaching tasks and his performance implementation. Also add, modify or delete what appropriate to the proposed training program.

In light of arbitrators' opinions and proposals the necessary modifications had made. The proposed training program is therefore valid for application to the exploratory sample, so it becomes on its final form to be applied on the sample of research.

method. So the note card has been prepared according to the following stages:

\section{-Determine the aim of note card:}

The aim behind building a note card is notice and measure the performance level for science teachers in Islamic secondary schools in the classroom. It should be applied before expose them to the proposed training program. Then, measure this performance in skill aspects to verify of the validity of research assumptions that concern with note card.

\section{- Instructions and guidelines:}

Instructions and guidelines have been set for the person who will do the noticeable process. Even the noticeable process completes accurately and correctly. These instructions are:

- Determine and Clarification nature of note card aim.

- Register teacher data whose performance will be observed.

- Focus and attention during the noticeable process.

- Observe teacher from the beginning of the lesson to the end.

- Observe teacher for more one lesson until all aspects and contents of the card are covered.

- The correct appreciate by using performance sign

$(\sqrt{ })$ with the suitable performance level. 
- Formulation of the initial image for the note card:

The note card has divided into two fields:

1- Methods of teaching and learning physics.

2- The educational techniques for teaching and learning physics.

\section{- Quantitative estimation for science teacher performance:}

The quantitative estimation method was used in the note card so that the individuals' response at two levels of performance is as follows:

- performed: When the science teacher performs the skill will get the degree (1).

- not performed: When the science teacher doesn't perform the skill will get the degree (0).

The observer will put $(\sqrt{ })$ in the field which determines the science teacher performance. It has been noticed.

The note card considers reliable if it measures the item for which it was actually placed. (Awda, 188:1998). It emphasizes the effectiveness of this instrument and its efficiency in measuring what is characterized. In order to make sure about reliability of the note card the two researcher have expose the note card on the experts in Educational and Psychological Sciences. All these steps have performed to ensure that it covered all aspects such as the correctness of its classification, the integrity of its vocabularies formulation in each field and the addition or deletion of any items of the note card. As well as the validity, accuracy and clarity of paragraphs for the purpose of making their notes. The researchers have some of the procedures and modifications in the light of the experts' proposals. The arbitrators' comments especially the language formulation were adhered. Thus the note card becomes in its final form contained 
paragraphs and (2) appendix. The two researchers consider the arbitrators' approval on the note card making the proposed modifications by them as the logical authenticity for the instrument.

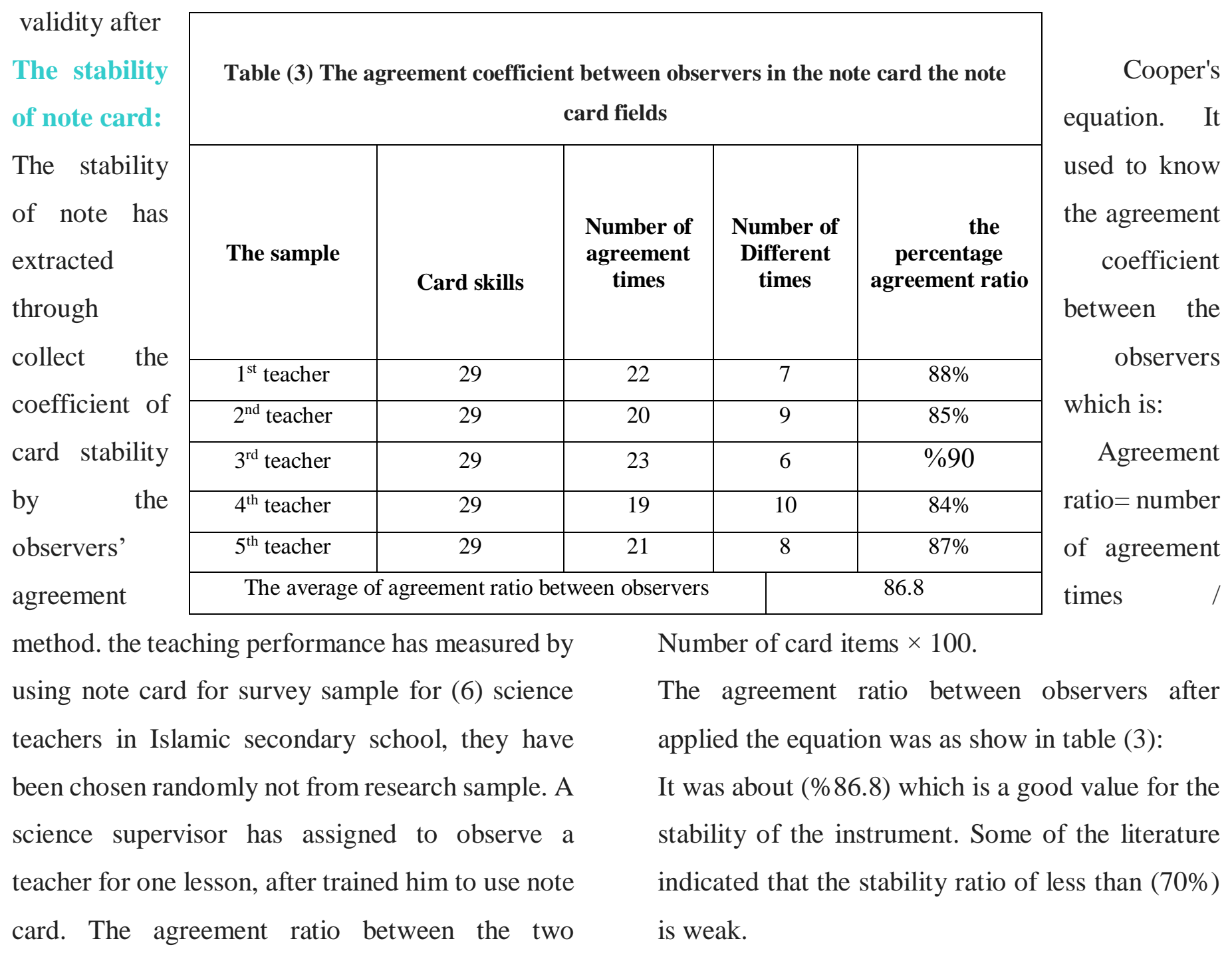

researcher and the supervisor have done by using 


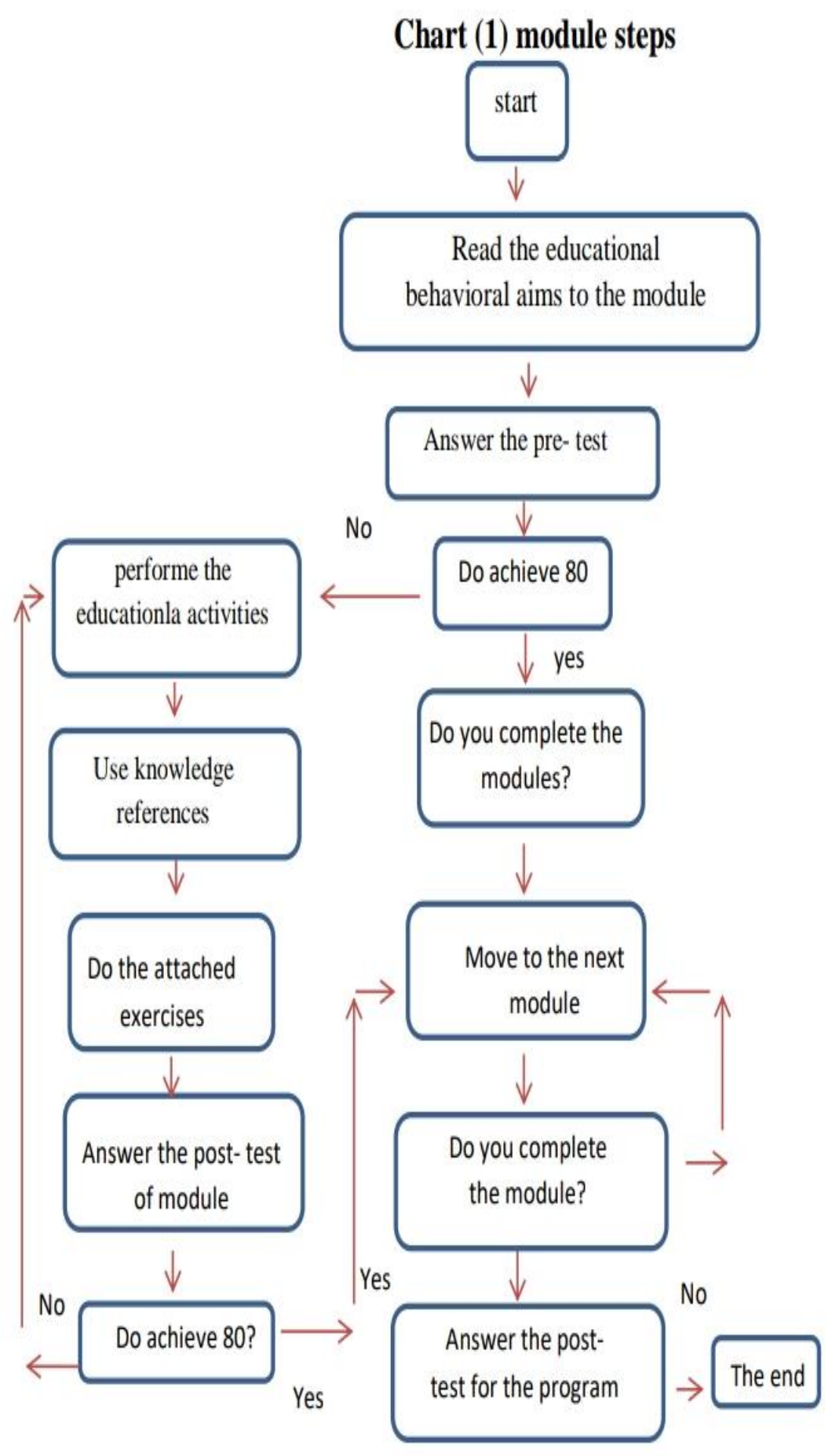

\section{Display and interpret results}

\section{Verification of assumptions reliable}

It has verified of research assumptions reliability through answer the third question of research questions which states (what is the activity of proposed program to develop the teaching performance for science teachers in Islamic secondary school, research

www.psychologyandeducation.net sample)? as it shows in the following:

\section{1- The results of applied the collecting test:}

The results of applied collecting test have explained in the light of first assumption of research which states ("There is a statistically function difference between the average score of 
the science teachers in the experimental group in pre and post applications to the collecting test - for measuring the cognitive aspect - and for the post-application.

Table (4)

Results of the collecting test (as all) for science teachers in Islamic secondary schools (research sample) in pre and post application.

\begin{tabular}{|l|l|l|l|l|l|l|l|l|}
\hline Application & $\begin{array}{l}\text { Number } \\
\text { of } \\
\text { teachers }\end{array}$ & $\begin{array}{l}\text { Average } \\
\text { account }\end{array}$ & $\begin{array}{l}\text { Deviation } \\
\text { standard }\end{array}$ & $\begin{array}{l}\text { Difference } \\
\text { between } \\
\text { two } \\
\text { averages }\end{array}$ & $\begin{array}{l}\text { Average } \\
\text { standard } \\
\text { error }\end{array}$ & $\begin{array}{l}\text { Freedom } \\
\text { degree }\end{array}$ & $\begin{array}{l}\text { T } \\
\text { values }\end{array}$ & $\begin{array}{l}\text { Function } \\
\text { level } \\
\text { at } \\
(\mathbf{0 . 0 1})\end{array}$ \\
\cline { 1 - 5 } Pre & 21 & 46.14 & 6.347 & 33 & 1.35 & 20 & 19.5 & \\
\hline Post & 21 & 79.14 & 7.455 & & & & \\
\hline
\end{tabular}

Table (4) shows that there are statistically function differences at the level of (0.01) of "T" value between the average of the teachers' scores (research sample) in the pre and post -application in favor of the post application.

The average scores of teachers in pre- application was (46.14) while the average scores in the post application was (79.14) in a difference about (33).

2- (Eta-Square $\mathbf{\eta}^{2}$ ) Equation has used and (d) value which corresponding it.

It has used to calculate the (effect size) in function of (T) value to determine of the effect of the independent variable (the proposed training program based on modules) on the dependent
Calculation of the difference between the pre and post-application for pre and postcollecting test as a whole as shown in the following table: 


\begin{tabular}{|l|l|l|l|l|l|l|}
\hline $\begin{array}{l}\text { Proposed } \\
\text { training } \\
\text { program }\end{array}$ & $\begin{array}{l}\text { Teaching } \\
\text { performance }\end{array}$ & 19.5 & 20 & 0.95 & 4.35 & Large \\
\hline
\end{tabular}

Table (5) shows the effect size to the proposed training program based on modules. it was (4.35) at Cognitive side which is a large level in compared with the determined level by equation $(0.80)$.

\section{- Summary of the collecting test application} results for the proposed program:

the collecting test application results (that related to the cognitive side for the training program based on modules) showed differences in function level (0.01) Statistically among the average scores of the experimental group teachers in the pre and postapplications and in favor of the post-application.
This is for the program as a whole. It refers that the first assumption for research has achieve. Also there is an activity for the proposed training program based on modules to develop teaching performance (cognitive side included program) for science teachers in Islamic secondary schools (research sample). In this way we can verify the validity of the first assumption of the research.

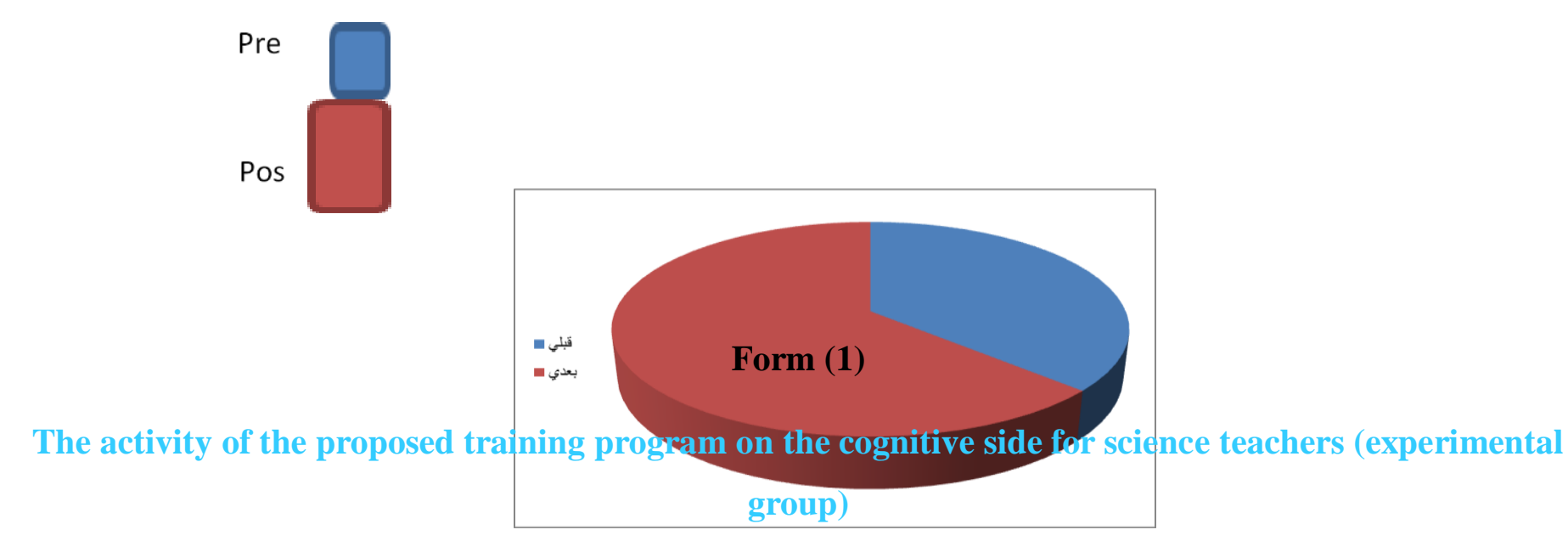

2- results of note card applied:

The results of note card applied has explained in the light of second assumption which states on "there is a difference with statistically function among average scores for science teachers the experimental group in the pre and postapplications to note card for teaches performance in skill side - for the benefit of post- application. In order to confirm the validity of the second assumption, the difference between the pre and post average application for note card has calculated as whole. It is also calculated separately for each module. as well as calculate the effect size of the independent variable "proposed training program" on the dependent variable "teaching performance for science teachers in Islamic secondary school" that associated with the skill side.

The average account, deviation standard, difference between two average, average standard error, $(\mathrm{t})$ value and its Statistically function are used 
to calculate the difference between the two average for pre and post- application as whole, as it shown next.
The calculate of difference between pre and post application for note card as whole will show in the following table:

Table (6) The results of the note card for science teachers' performance in Islamic secondary school in the pre and post- application

\begin{tabular}{|c|c|c|c|c|c|c|c|}
\hline Application & $\begin{array}{c}\text { Teachers } \\
\text { number }\end{array}$ & $\begin{array}{c}\text { Average } \\
\text { account }\end{array}$ & $\begin{array}{c}\text { Deviation } \\
\text { standard }\end{array}$ & $\begin{array}{c}\text { Difference } \\
\text { between } \\
\text { two } \\
\text { average }\end{array}$ & $\begin{array}{c}\text { Freedom } \\
\text { degree }\end{array}$ & $\begin{array}{c}\text { (t) } \\
\text { value }\end{array}$ & $\begin{array}{c}\text { Function } \\
\text { level at } \\
(0.01)\end{array}$ \\
\cline { 1 - 4 } pre & 21 & 25.82 & 20 & \multirow{2}{*}{21.96} & 20 & 25.82 & \\
\hline post & 21 & 55.86 & 2.29 & & \\
\hline
\end{tabular}

Table (6) shows that there are statistically function differences at the level of (0.01) to " $\mathrm{T}$ " value between the average scores of science teachers in the Islamic secondary schools (the research sample) in pre and post- application for the benefit of the post application.

The average scores of science teachers in the Islamic secondary schools (the research sample) in the pre application was (33.9) while the average scores on the post- application was (55.86). so the difference was (21.96). Table (4) shows that there are statistically function differences at the level of (0.01) and the freedom degree (20) between pre (33.9) and (55.86) post applications. The difference for the experimental group on the note card was about (21.96) between scores averages of pre and post- application to the note card in the benefit of post - application. This indicates the teaching performance development of science teachers in Islamic secondary schools (the experimental group) through applied to the proposed training program and thus the validity of the second assumption.

These results correspond with studies results of (Nuweihi, 2010), (Mikbl 2010), (Abdul Qawi, 2010), (Cameroon, M 2009.), (Bijee, 2006), (Abu al-Hamal, 2009), (Mikbl,2010), (Kaib,2014) and (Abu Sulait, 2013).

Third: (Eta- square $\eta 2$ ) equation and $(\mathrm{t})$ value have used to show the activity of the program. Also it used to calculate the effect size by function of ( $t)$ value to determine effect of the independent variable (proposed training program) on the dependent variable to develop teaching performance (the experimental group) that related to skill side as shows in table (7):

Table (7)

$\eta^{2}$, (d) values and the effect size of the proposed training program (note card)

\begin{tabular}{|c|c|c|c|c|c|c|}
\hline $\begin{array}{c}\text { Independent } \\
\text { variable }\end{array}$ & $\begin{array}{c}\text { dependent } \\
\text { variable }\end{array}$ & (t) values & $\begin{array}{c}\text { Freedom } \\
\text { degree }\end{array}$ & $\begin{array}{c}\text { Eta-Square- } \\
2 \eta\end{array}$ & $\begin{array}{c}\text { (d) } \\
\text { value }\end{array}$ & Effect size \\
\hline $\begin{array}{c}\text { Proposed } \\
\text { training } \\
\text { program }\end{array}$ & $\begin{array}{c}\text { Teaching } \\
\text { performance to } \\
\text { physics } \\
\text { teachers }\end{array}$ & 25.82 & 20 & 0.974 & 6.11 & Large \\
\hline
\end{tabular}

Table (7) shows the effect size of the proposed training program in the development of the training performance for science teachers in Islamic secondary schools (skill level) which was (6.11). It is a large level compared to level that determined by equation $(0.8)$.

The results of the note card applied (skill side) for proposed program have assured that the research 
assumption and activity of the training program to develop skill side for science teachers in Islamic secondary schools (the experimental group) has achieved. Table (2), the two researchers attribute that for the following:

The success of modules in prepare and building the proposed training program. Then develop teaching performance for science teachers in Islamic secondary schools (experimental group). As well as the secretion of the basic structure of the experiments to be taught. This will help to save time and effort. It also helped to show the spirit of cooperation among science teachers for being take into account the individual differences, many studies have confirmed what was mention above such as study each of (Al-Saray, 2000), (Ibrahim, 2002), (Barwari, 2001) and (Khawaldeh, 2003). The proposed program helps to use various constructive methods such as (pre, constructively and post) and Feedback. The science teacher recognizes the strengths and weaknesses aspects of his performance in order to improve and develop it. Also his progress extent toward program aims.

- the proposed program has prepared and built in the light of training needs for science teachers in Islamic secondary schools. Whereas teachers have been one of the main sources to identify training needs. so this led to their active participation in the proposed program, and then development of their teaching performance.

The program provided science teachers in Islamic secondary schools with opportunities to practice effective teaching skills and modern methods in education and learning sciences. then the participation of their colleagues in educational situations and exchange of experiences.

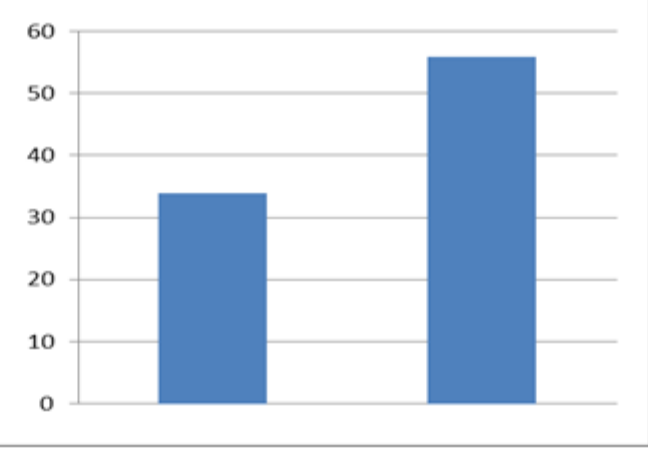

\section{Form (2) The activity of proposed training program in development the skill side for science teacher in Islamic secondary schools (the experimental group)}

\section{Resullts explanations:}

The former results explain approved research assumptions and proved from the table (7) that illustrates in form (2). It means that there are statistically function differences between the experimental group averages performance in pre and post- application in each of collecting test for content of program and note card in benefit of postapplication. The two researches attribute the development in performance of science teachers in Islamic secondary school for many reasons. The most important reason is the proposed training program based on module which has been applied to them. as well as using modern training methods in implement of the proposed program content. it allows the teachers of science to build knowledge and skill logically. it makes him in the position of responsibility to deal with educational situations with clear steps to achieve the educational aims accurately and keep up with modernity in his teaching performance. the proposed program activity has been clearly demonstrated by its statistical function, but it has been more obvious in the field of teaching and learning science.

\section{Recommendations:}

1- the serious pursuit to keep up the modernity in prepare and build training programs for science teachers in different fields and in accordance with the conditions of religious education and Islamic studies.

2- Training programs should be prepared in the light of scientific standards and foundations with 
experienced supervised in order to achieve the educational aims.

3- The use of modules in the prepare and build of training programs for science teachers in Islamic secondary schools in its broad sense. Also it takes into account the individual differences, and provide alternatives through feedback to the program.

4- set motivations and rewards for participants in the training programs for science teachers in Islamic secondary schools by employers to develop their motivation to participate in these programs.

5- Develop scientific research in the field of training programs prepare for science teachers in Islamic secondary schools by financing them, and adopting educational institutions to the results of these researches to improved output and achieve aims. These researches should be the basis in build of those programs.

6- the necessity of continuous evolution to the training programs for science teachers in Islamic secondary schools. This evolution used to identify and develop strength points, and weakness points to avoid and to address deficiencies in the programs that follow.

7- The need of taking into account the temporal, spatial and functional conditions for science teachers in Islamic secondary schools when REFERNCES

1. Abu Al-Hamawi, Ahmed Abdul Majid Ali (2005): "The effectiveness of a proposed training program for the biology teachers in Saudi Arabia in their professional needs".

2. Abu Salait, Abdullah Yahya Ahmad (2007): "Reading the biology book for the first grade and the science of the ninth grade and its relation to collection, gender and region." unpublished Master Thesis, Faculty of Education, Sana'a University.

3. Acene . R.Hawes, Lynne Salop Hawes( 1982) : " The Concise Dictionary of Education " Nostr and Reinhold Australia, New York, U.S, p.199.

4. Al Janabi, Ammar Hadi (2011): Effectiveness of Training of Students Applied to Metacognitive Strategies in their Mathematical Communication and Teaching Performance, Unpublished PhD implementing the training programs prepared for them, in order to be positive in their participation in the activities of these programs and thus achieve their educational aims.

\section{Suggestions:}

1- Conduct similar researches to be applied on teachers of study materials in Islamic secondary schools.

2- study the activity of training programs in modification wrong concepts in sciences and develop skills of critical and creative thinking for Islamic secondary schools' students.

3- Conducting a field study of several methods for the development teachers of Scientific specialties professionally and to stand on the results and identify methods that appropriate their reality in all areas.

4-prepare guidelines to conduct some of teaching and learning sciences methods through the use of modern educational techniques to reach to advanced teaching level.

5- A project can be proposed in the light of the current research results entitled (training program based on modules to develop of scientific inquiry skills through science education technology and its impact on the development of critical thinking skills and scientific creativity for their students.

Thesis, Baghda University, Ibn al-Haytham College.

5. Al Saray, M.Jassim Sulaiman (2000): The Effect of Designing a System-Based Educational Program in the Development of Some Skills of Teaching Mathematics in Applied Students, unpublished doctoral dissertation, Faculty of Education Ibn AlHaytham / University of Baghdad.

6. Al-Barwari, Ahmed Abdel-Salam (2001):" Using Systems Method in Teaching the Production of Multipurpose Educational Computer Programs", Unpublished $\mathrm{PhD}$ Thesis, Faculty of Education, Helwan University.

7. Al-Safasifa, Abdul Rahman Ibrahim (2005): Administration of Education and classroom Education, Jordan, Karak, Yazid Center for Publishing.

8. Al-Saied Ismail, Wehbe (2002): Contemporary Trends in Evaluating Teacher Performance, 14th Scientific 
Conference of the Egyptian Society for Curriculum and Teaching Methods, Vol. II, 24-25 July, p. 756.

9. Al-Shennawi, Abdel-Moneim and Nasr Mohamed Mahmoud (1991): personal skills in teaching the students of primary school and their relation to some of their personal characteristics, Journal of the Faculty of Education, Zagazig University, No. 14, January, p.

10. Al-Sherbini, Fawzi and Effat al-Tannawi (2006): "Educational Modules in the Age of Informatics", Al-Kuttab Publishing Center, p. 54, 55 .

11. Anbo Saidi, Yahya (2005): "The Effectiveness of a Training Program in the Development of Some Vocational Competencies of Teachers of Islamic Education in Basic Education in the Sultanate of Oman", unpublished $\mathrm{PhD}$ thesis, Girls College, Ain Shams University.

12. Andersson,N.(2000) : Participatory Approaches to Teacher Training. Journal of Research in Science Teaching, Vol,11No. (2),2000, pp144-166.

13. Beji, Muhammad Hamza (2006): "A proposed training program for science teachers in the primary stage in light of their training needs".

14. Cameroon, M. (2009): Professional Development and its Impact on Teacher Practice, University of Southern California.

15. Carolyen, S. (2006): Teachers Perceptions and Use of a Large Scale Science Education Reform Initiative for Middle Schools. Unpublished Doctoral Dissertation, University of Alabama, United States, pp 1185.

16. Danche, V. and Others (2004): Beliefs about Learning Environment: How Do Student Teacher Think Reflect and Act Concerning Self-Regulated and Cooperative Learning in Flanders (Melgium), Paper Presented at the Annual Meeting of American Educational Research Association 84, Chicago, 21-25 April. pp 141-150.

17. Diab, Ismail Mohamed and Adel Al-Saeed Al-Banna (2001): Assessment of the quality of university performance, Egypt, the Egyptian Library, p. 35.
18. Dillon, J.; Osborne, J.; Fairbrother, B.\&Kurina.L.(2000): A Study into the Professional View and Needs of Science Teachers in Primary and Secondary Schools in England. London. Kings College London, P2.

19. ERDEMIR, Naki. Department of Elementary Science Education, Faculty of Education, University of Yüzüncü Y1l, Van, TURKEY. Email: nakierdemir@gmail.com. Received 5 Nov., 2009. Revised 8 Dec., 2009

20. Foreign sources- Gamal, Abdul Rahman Abdul Salam (1995): "The effectiveness of educational modules and cognitive development in the development of the competencies of measurement and evaluation of the students of teacher institutes in Yemen."

21. Gamal, Abdurrahman Abdel Salam (2000): "Self-learning with educational pedagogy", p. 67.

22. Gordon, J. and Nhjhof, W. (2002): Effect of Complex Feed Back on Computer Assisted Modular Instruction", Journal of Education Technology, Vol. 39. Issue 2, Sep, pp 180183.

23. Grade Mathematics Classroom" Educational Studies in Mathematic, Vol. 53, No 3. Pp181-183.

24. Ibrahim, Mohammed Reda (2002): Systemic Approach and Practice of Extracurricular Activities, Second Arab Conference on Systemic Approach in Teaching and Learning, Center for the Development of Science Teaching, Ain Shams University, Cairo.

25. Jamil, Abdul Rahman Abdul Salam (1995), The Effectiveness of Educational Models and the Growth in the Development of Measurement and Evaluation Capacities of Students of Teacher Institutes in Yemen ", PhD Thesis, Faculty of Education, Tanta University.

26. Kent, A. (2001): Improving Teacher Quality Through Professional Development. Educational Leadership, 124 (3).

27. Khawaldah, Muhammad (2003): Knowledge Building System and Methods of Teaching, 3rd Arab Conference on "Systemic Approach in Teaching and 
Learning", Ain Shams University, Cairo, April 2003.

28. Rudolph, A. (2002): The Effects of RolePlay as A Method in Classroom Management Courses on In-service Teachers "Attitudes and Effectiveness, Eric Document Reproduction Service No. AAC3055344.

29. Shehab, M. Abdul Sabour and Umniah ElSayed El-Jendi (1998): Use of educational modules to develop the understanding of the female student in the faculty of girls for the nature of science, science learning and teaching methods", Second Conference of the Egyptian Society for Scientific Education ", vol 1.

30. Shehata, Hassan and Zeinab Al-Najjar (2003): Dictionary of Modern Terminology, Egyptian Lebanese Dar.

31. Shinta, Jalal (2009): Building a training program for physics teachers on the patterns of psychotropic stimulants and its impact on their performance, achievement and scientific thinking of their students, unpublished $\mathrm{PhD}$ thesis, Baghdad University, Ibn al-Haytham College.
32. Shinta, Jalal (2009): Building a training program for physics teachers on the patterns of psychotropic stimulants and its impact on their performance, achievement and scientific thinking in their students, unpublished $\mathrm{PhD}$ thesis, Baghdad University, Ibn al-Haytham College.

33. Stcophen, J.; Clare, B. and Fife, Y. (2003): Developing Mathematical Thinking and Self- Regulated Learning: A Teaching Experiment in a Seventh

34. Tamam, Shadia Abdel Halim and Omaima Mohamed Afifi (2010): "The effectiveness of a proposed training program to develop the capacity of faculty members in light of their training needs."

35. Victorina, A., Eveleyn, S. \& Herminia, O. (2004): Principles and Strategies of Teaching, Philippine: Rex Bookstore, Inc.

36. Warwich, D. (1996): Modular curricula, International Encyclopedia of Zaytoon, Ayesh (2008): Methods of Teaching Science, Jordan, Amman, Dar Al Shorouk. 